\title{
Specific Gravity and Dimensional Stability of Boron-Densified Wood on Three Lesser-Used Species from Indonesia ${ }^{1}$
}

\author{
Sarah AUGUSTINA ${ }^{2} \cdot$ Imam WAHYUDI $^{3, \dagger} \cdot$ I Wayan DARMAWAN $^{3} \cdot$ \\ Jamaludin $\mathrm{MALIK}^{4} \cdot$ Efrida $\mathrm{BASRI}^{4} \cdot{\text { Yoichi } \mathrm{KOJIMA}^{5}}^{5}$
}

\begin{abstract}
Effect of pre-treatment and compression ratio on specific gravity (SG) and dimensional stability improvement of three lesser-used wood species from natural forest area of North Kalimantan Province, Indonesia had been investigated. Hot soaking at $80^{\circ} \mathrm{C}$ for 3 hours within 2 and $5 \%$ of boron solution was applied as pre-treatment, while compression ratio applied was 20 and $40 \%$ from the initial thickness. Densification was conducted using hot pressing machine at $30 \mathrm{~kg} / \mathrm{cm}^{2}$ of pressure and $160^{\circ} \mathrm{C}$ of temperature for 15 minutes. Specific gravity was measured gravimetrically, while dimensional stability was evaluated through thickness swelling and water absorption as the indicator. Results show that SG of densified wood was influenced by wood species and compression ratio, but not by pre-treatment applied; while dimensional stability was influenced by wood species, compression ratio, and pre-treatment. Specific gravity and water absorption of densified wood was improved significantly. Specific gravity increased $28.86-63.03 \%$, while water absorption decreased $12.80-15.89 \%$. Thickness swelling of $20 \%$ densified wood was lower than that of $40 \%$ densified wood.
\end{abstract}

Keywords: boron, compression ratio, densification, dimensional stability, lesser-used wood species, specific gravity

\section{INTRODUCTION}

Wood supply as raw material for Indonesian timber industries during the last 5 years has been declined significantly from 47.8 million $\mathrm{m}^{3}$ in 2013 to 22.2 million $\mathrm{m}^{3}$ in 2016 (BPS 2017). Besides declining of forest productivity, decreasing in wood supply is mainly caused by dependence of wood industries on certain wood species especially member of Dipterocarpaceae.
Therefore, species diversification is needed since there are 4000 trees species exist in Indonesian tropical rainforest which are potential as wood producer (Martawijaya et al., 2005). According to Ali (2011); Marbun et al. (2019), species diversification could reduce the pressure on commercial wood species and promote several lesser-used species (LUS) as raw material for the future. In order to promote their utilization, information of basic properties of these woods

\footnotetext{
${ }^{1}$ Date Received March 7, 2020, Date Accepted May 12, 2020

${ }^{2}$ Forest Products Science and Technology Study Program, IPB University, Bogor 16680, Indonesia

${ }^{3}$ Forest Product Department, Faculty of Forestry, IPB University, Bogor 16680, Indonesia

${ }^{4}$ Forest Products Research and Development Agency (FORDA), Bogor 16610, Indonesia

${ }^{5}$ Wood Biomass Utilization Department, Faculty of Agriculture, Shizuoka University, Shizuoka 422-8529, Japan.

† Corresponding author: Imam WAHYUDI (e-mail: imyudarw16@yahoo.com, ORCID: 0000-0001-9062-9264)
} 
Specific Gravity and Dimensional Stability of Boron-Densified Wood on Three Lesser-Used Species from Indonesia

is required.

From previous studies it is known that many of LUS are categorized as secondary timber due to lower in dimensional stability, strength, and natural durability. FAO (1984) stated that LUS is wood species that is less commercially acceptable or less profitable and mostly left out in the forest during logging. As timber, therefore, their characteristics have to be improved. According to Rowell (1990); Hill (2006), dimensional stability and specific gravity can be improved by modifying the wood through several improvement techniques. Among the existing techniques, densification is an effective one.

Wood densification consists of four stages i.e. plasticization or cell wall softening, compression in the softened state, setting in the deformed state, and fixing the deformed state (Morsing and Hoffmeyer, 2000). Among them, cell wall softening is very important stage and related to glass transition temperature of lignin (Gašparik and Barcik, 2014). Several studies suggested that glass transition temperature for lignin varies from 50 to $100{ }^{\circ} \mathrm{C}$ (Kelley et al., 1987; Furuta et al., 1997; Kong et al., 2017). According to Wistara et al. (2017), glass transition temperature of lignin is considered as a critical point for an effective densification process.

In general, densification is carried out by pressing the wood at certain temperature and pressure for predetermined period of time. In order to obtain the best result, several pre-treatments can be applied. Khalil et al. (2014); Navi and Sandberg (2012); Yunianti et al. (2019) proved that water boiling and steaming are able to soften wood cell and weaken fiber bond, so that the wood is easier to be flatten during pressing. Temperature above glass transition results in increasing in mobility of wood polymer, and as a result wood cells can be rearranged (Danu et al., 2013).

Hot soaking using boron solution as pre-treatment has several advantages. It is easier penetrates into wood cell, can reduce cell damage, and improve durability of wood as well (Kartal et al., 2007). Unfortunately, wood cell will be deformed during densification. Compression ratio, therefore, has to be determined in order to avoid the excessive deformation. According to Shmulsky and Jones (2011), compression ratio is influenced by wood density, proportion of cell cavities, composition of wood structures, and wood moisture. Appropriate of compression ratio applied is able to improve dimensional stability especially swelling thickness, as well as wood density and specific gravity of wood. Bucur et al. (2000) stated that wood density of spruce increased by $26 \%$ after pressing with $30 \%$ of compression ratio, while density of cherry increasesby $46 \%$. Furthermore, swelling thickness of randu board decreases after pressing with $60 \%$ of compression ratio (Danu et al., 2013).

Until now study on densification is mostly related to the commercial wood species (Zhang et al., 2000; Korkut et al., 2008; Bal and Bektas, 2012; Lahtela and Karki, 2014). Study on boron-densified wood especially using LUS from tropical rainforest is still limited. Furthermore, our previous study showed that specific gravities of nyatoh (Palaquium lanceolatum), sepetir (Sindora wallichii) and pisang putih (Mezzettia leptopoda) woods are less than 0.50. Therefore, the main objective of this study was to investigate effects of pre-treatment and compression ratio on specific gravity and dimensional stability improvement on densified wood of these three LUS. Hot-soaking within 2 and $5 \%$ of boron solutions was determined as pretreatment, while compression ratio applied was 20 and $40 \%$ from the initial thickness.

\section{MATERIALS and METHODS}

\subsection{Materials}

Logs in length of $120 \mathrm{~cm}$ and diameter of 50 to 
Table 1. Treatment used in this study

\begin{tabular}{|c|c|c|c|c|c|}
\hline No & Treatment & \multicolumn{2}{|c|}{ Pre-treatment } & Densification & Size of samples $\left(\mathrm{cm}^{3}\right)$ \\
\hline 1 & None (control) & & - & - & $2 \times 2 \times 2$ \\
\hline 2 & 2B0CR & Hot-soaking & within $2 \%$ boron & - & $2 \times 2 \times 2$ \\
\hline 3 & $5 \mathrm{~B} 0 \mathrm{CR}$ & Hot-soaking & within $5 \%$ boron & - & $2 \times 2 \times 2$ \\
\hline 4 & 0B20CR & & - & $20 \%$ compression ratio & $2 \times 2 \times 2.4$ \\
\hline 5 & 2B20CR & Hot-soaking & within $2 \%$ boron & $20 \%$ compression ratio & $2 \times 2 \times 2.4$ \\
\hline 6 & $5 \mathrm{~B} 20 \mathrm{CR}$ & Hot-soaking & within $5 \%$ boron & $20 \%$ compression ratio & $2 \times 2 \times 2.4$ \\
\hline 7 & 0B40CR & & - & $40 \%$ compression ratio & $2 \times 2 \times 2.8$ \\
\hline 8 & 2B40CR & Hot-soaking & within $2 \%$ boron & $40 \%$ compression ratio & $2 \times 2 \times 2.8$ \\
\hline 9 & 5B40CR & Hot-soaking & within $5 \%$ boron & $40 \%$ compression ratio & $2 \times 2 \times 2.8$ \\
\hline
\end{tabular}
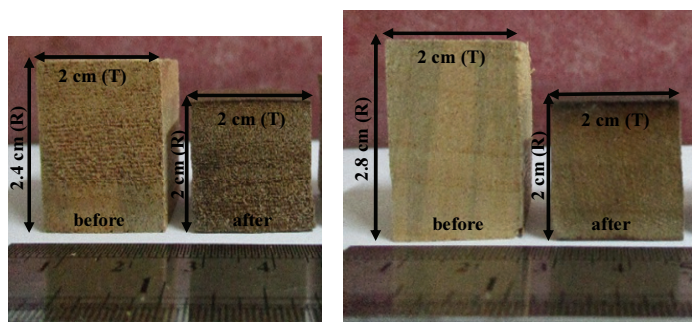

Fig. 1. Sample size before and after densification: (a) $20 \%$ of compression ratio (b) $40 \%$ of compression ratio.

$60 \mathrm{~cm}$ from PT Intracawood Manufacturing, Tarakan, North Kalimantan Province namely nyatoh (P. lanceolatum), sepetir ( $S$. wallichii), and pisang putih (M. leptopoda) in air dried condition were used as the main sample. The logs were band-sawed into samples for nine treatments (Table 1) and classified into three categories i.e. $2 \times 2 \times 2 \mathrm{~cm}^{3}$ (longitudinal $\times$ tangential $\times$ radial direction) for control and without densification, $2 \times 2 \times 2.4 \mathrm{~cm}^{3}$ for $20 \%$ of compression ratio, and 2 $\times 2 \times 2.8 \mathrm{~cm}^{3}$ for $40 \%$ compression ratio as shown on Fig. 1. With 15 replications for each treatment, therefore, total number of samples was 405 pieces.

\subsection{Methods}

\subsubsection{Densification process}

Before pressing, wood samples were hot soaking within 2 and $5 \%$ boron solutions separately at $80{ }^{\circ} \mathrm{C}$ for 3 hours as pre-treatment (Ramos et al., 2006; Laser et al., 2009). The samples were then hot pressed at temperature of $160{ }^{\circ} \mathrm{C}$ and pressure of $30 \mathrm{~kg} / \mathrm{cm}^{2}$ for 15 minutes with loading rate of $6 \mathrm{~mm} /$ minutes in tangential surface with compression ratio of 20 and $40 \%$ from initial thickness. The boron-densified wood was left overnight under pressure for cooling down. Boron solution is a mixture of boric acid and sodium bicarbonate $(1: 1)$.

\subsubsection{Compression-set and compression-set recovery measurements}

Compression set was used to determine thickness variation of wood after densification. Compression set was measured according to Equation 1:

$$
\text { Cset }(\%)=\frac{\text { To-Ta }}{\text { To }} \times 100
$$

Where:

Cset $=$ Compression set $(\%)$

To $=$ Initial thickness before densification $(\mathrm{mm})$

$\mathrm{Ta}=$ Oven-dried thickness after densification $(\mathrm{mm})$

Densified wood samples were oven-dried for 3 hours and then soaked in water at room temperature for 24 hours and re-oven-dried for 24 hours to measure compression-set recovery (CSR). The value of CSR was measured according to Equation 2: 
Specific Gravity and Dimensional Stability of Boron-Densified Wood on Three Lesser-Used Species from Indonesia

$$
\operatorname{CSR}(\%)=\frac{\text { Tss-Tsb }}{\text { To-Tsb }} \times 100
$$

Where:

Cset $=$ Compression-set recovery $(\%)$

To = Initial thickness before densification $(\mathrm{mm})$

$\mathrm{Tsb}=$ Oven-dried thickness before swelling $(\mathrm{mm})$

Tss $=$ Oven-dried thickness after swelling $(\mathrm{mm})$

\subsubsection{Specific gravity measurement}

Specific gravities (SG) of wood either control or after treatment were measured by gravimetric method. The values were calculated according to Equation 3 and 4:

$$
\begin{aligned}
& \mathrm{SGc}=\frac{\mathrm{BKTc} / \mathrm{VKUc}}{\rho \text { standard }} \\
& \mathrm{SGa}=\frac{\mathrm{BKTa} / \mathrm{VKUa}}{\rho \text { standard }}
\end{aligned}
$$

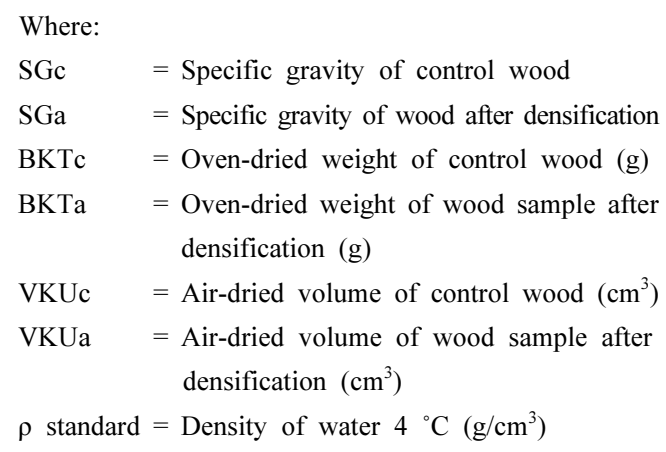

\subsubsection{Dimensional stability measurement}

Dimensional stability of wood either control or after treatment was evaluated by thickness swelling (TS) and water absorption (WA) after soaking for 24 hours. Thickness swelling and WA were measured according to Equation 5 and 6:

$$
\begin{aligned}
& \mathrm{TS}=\frac{\text { Tss-Tsb }}{\mathrm{Tsb}} \times 100 \\
& \mathrm{WA}=\frac{\text { Bss-Bsb }}{\text { Bsb }} \times 100
\end{aligned}
$$

Where:

$\mathrm{TS}=$ Thickness swelling $(\%)$

$\mathrm{Tsb}=$ Oven-dried thickness before swelling $(\mathrm{mm})$

Tss $=$ Oven-dried thickness after swelling $(\mathrm{mm})$

$\mathrm{WA}=$ Water absorption $(\%)$

$\mathrm{Bsb}=$ Oven-dried weight before swelling $(\mathrm{g})$

Bss = Oven-dried weight after swelling $(\mathrm{g})$

\subsubsection{Wood porosity measurement}

Porosity of wood was characterized by measuring the percentage of void volume, vessel diameter, fiber diameter, vessel frequency, and ray parenchyma frequency. Void volume was measured according to Equation 7 (Ulvcrona et al., 2006):

$$
\text { Void volume }=\left(1-\left(\frac{\text { SG od }}{\text { SG zk }}\right)\right) \times 100
$$

Where:

SG od = Specific gravity of wood in oven-dried condition

SG $\mathrm{zk}=$ Specific gravity of cell wall $(=1.50)$

Vessel diameter and vessel frequency were measured macroscopically in cross section (X), while ray frequency through microtome specimen in tangential section (T). Measurement of fiber diameter was conducted through macerated specimen obtained by modification of Franklin's method (Rulliaty 1994). Vesseland fiber diameter were measured using 50 individual cells, while vessel- and ray frequency were measured 3 times repetitions per observation field.

\subsubsection{Anatomical structure observation}

Anatomy structures were observed macroscopically by using light microscope and by SEM JEOL JSM$6510 \mathrm{LV}$, Japan. Before observing, samples were vacuum dried and coated using JEOL JEC-3000FC Auto fine coater with gold $(A u)$ for $120 \mathrm{~s}$ and $30 \mathrm{~mA}$. 


\subsubsection{Data analysis}

Randomized factorial design with three factors was applied for analysis of variance (ANOVA). The factors were wood species (three level), compression ratio (three level), and boron concentration (three level). Each treatment combination was carried out in fifteen replications. The obtained data were summarized in the average and standard deviation by using Microsoft Excel. ANOVA was conducted to evaluate the effect of species, compression ratio, and boron concentration on specific gravity and dimensional stability of wood. Significant differences of variables within each factor and the interaction between the factors were determined using Duncan's multiple range test.

\section{RESULTS and DISCUSSION}

\subsection{Specific gravity}

Wood densification is one of quality improvement technique to modify wood characteristics by using certain pressure, temperature, and times. After densification, the wood becomes denser (Laine et al., 2014). These structural changes have an impact on increasing wood strength, especially its SG. Recapitulation of SG of three wood species studied was presented in Table 2. It can be seen that compared to wood control, SG of densified wood with and without pre-treatment increased significantly. Specific gravity of nyatoh and pisang putih wood tended to increase, but SG of sepetir wood was almost constant. Analysis of variance shows that wood species and compression ratio had a significant effect on SG $(\mathrm{P}<0.05)$ (Table 3$)$. The Duncan's range test shows that SG of densified wood was varied among species and among compression ratio level. According to Zhao et al. (2015), there is a linear relationship between flattening wood cell and the SG. Higher compression ratio results in higher in SG due to more flatten of the wood cell.

SEM observation showed a small amount of boron inside cell cavity of the treated wood (Fig. 2). According to Ramos et al. (2006); Lesar et al. (2009), boron compound does not bind chemically to wood cell walls. It has physical adsorption bonds like van der Waals bonds and hydrogen bonds but in a weak condition. Ramos et al. (2006) also stated that impregnated woods by boron compounds (boric acid and borax) have a leaching rate around $97 \%$ for boric acid

Table 2. Specific gravity of three wood species

\begin{tabular}{|c|c|c|c|}
\hline \multirow{3}{*}{ Treatment } & \multicolumn{3}{|c|}{ Specific gravity } \\
\hline & \multicolumn{3}{|c|}{ Species } \\
\hline & Nyatoh & Pisang Putih & Sepetir \\
\hline None (control) & $0.42 \pm 0.05^{\mathrm{c}}$ & $0.37 \pm 0.05^{\mathrm{b}}$ & $0.32 \pm 0.03^{\mathrm{a}}$ \\
\hline 2B0CR & $0.44 \pm 0.04^{\mathrm{cd}}$ & $0.42 \pm 0.07^{\mathrm{a}}$ & $0.32 \pm 0.05^{\mathrm{a}}$ \\
\hline $5 \mathrm{~B} 0 \mathrm{CR}$ & $0.45 \pm 0.04^{\text {cde }}$ & $0.44 \pm 0.07^{\mathrm{a}}$ & $0.32 \pm 0.04^{\mathrm{a}}$ \\
\hline $0 \mathrm{~B} 20 \mathrm{CR}$ & $0.55 \pm 0.06^{\mathrm{hi}}$ & $0.50 \pm 0.06^{\mathrm{fg}}$ & $0.42 \pm 0.02^{\mathrm{c}}$ \\
\hline 2B $20 \mathrm{CR}$ & $0.54 \pm 0.05^{\mathrm{gh}}$ & $0.51 \pm 0.04^{\mathrm{fg}}$ & $0.42 \pm 0.03^{\mathrm{c}}$ \\
\hline $5 \mathrm{~B} 20 \mathrm{CR}$ & $0.55 \pm 0.07^{\mathrm{hi}}$ & $0.51 \pm 0.05^{\mathrm{fg}}$ & $0.42 \pm 0.04^{\mathrm{c}}$ \\
\hline 0B40CR & $0.62 \pm 0.06^{\mathrm{jk}}$ & $0.59 \pm 0.06^{\mathrm{jk}}$ & $0.49 \pm 0.06^{\mathrm{fg}}$ \\
\hline 2B40CR & $0.62 \pm 0.04^{\mathrm{ij}}$ & $0.57 \pm 0.03^{\mathrm{hij}}$ & $0.49 \pm 0.04^{\mathrm{def}}$ \\
\hline 5B40CR & $0.62 \pm 0.05^{\mathrm{k}}$ & $0.60 \pm 0.03^{\mathrm{jk}}$ & $0.49 \pm 0.05^{\mathrm{ef}}$ \\
\hline
\end{tabular}

Note: Specific gravity values are averages of 15 replications. Values within a column followed by the same letter are not significantly different at $5 \%$ significance level using Duncan's multiple range test. 
Specific Gravity and Dimensional Stability of Boron-Densified Wood on Three Lesser-Used Species from Indonesia

Table 3. Analysis of variance for each parameter

\begin{tabular}{|c|c|c|c|c|c|c|c|}
\hline \multirow{2}{*}{ Parameter } & \multicolumn{7}{|c|}{ Factor } \\
\hline & JK & $\mathrm{CR}$ & PP & $\mathrm{JK} * \mathrm{CR}$ & $\mathrm{JK}^{*} \mathrm{PP}$ & $\mathrm{PP} * \mathrm{CR}$ & $\mathrm{JK}^{*} \mathrm{PP} * \mathrm{CR}$ \\
\hline Specific gravity & $* *$ & $* *$ & ns & $* *$ & ns & $\mathrm{ns}$ & ns \\
\hline C-set & $* *$ & $* *$ & $* *$ & ns & $\mathrm{ns}$ & ns & ns \\
\hline CSR & $* *$ & $* *$ & $* *$ & $*$ & $\mathrm{~ns}$ & $\mathrm{~ns}$ & $\mathrm{~ns}$ \\
\hline Thickness swelling & $* *$ & $* *$ & $* *$ & $*$ & ns & $* *$ & ns \\
\hline Water absorption & $* *$ & $* *$ & $* *$ & ns & $* *$ & $* *$ & ns \\
\hline
\end{tabular}

Note: ns: not significant; *: significantly different at $5 \%$ level; **: significantly different at $1 \%$ level; JK = wood species; $\mathrm{CR}=$ compression ratio; $\mathrm{PP}=$ pre-treatment.
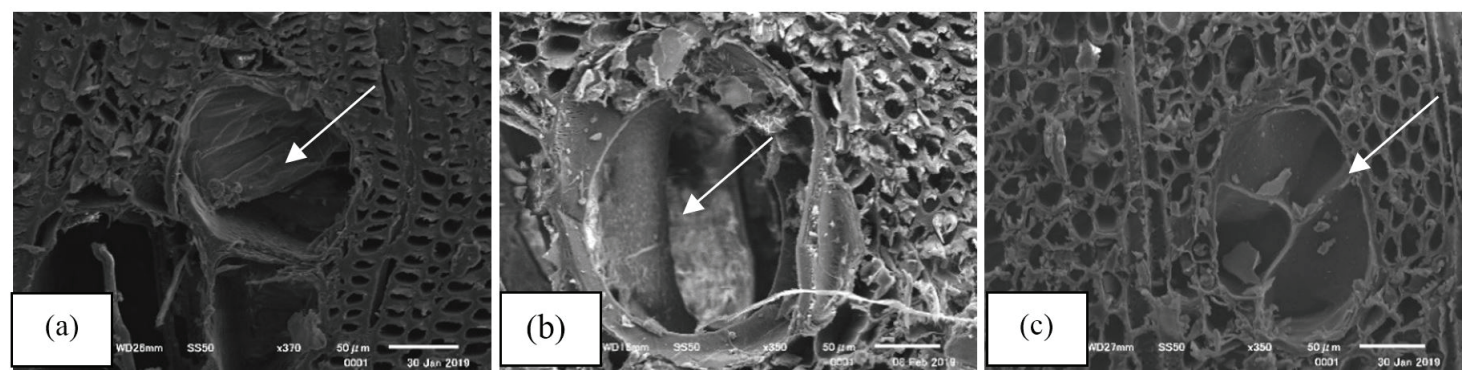

Fig. 2. Boron penetration observed with Scanning Electron Microscope: (a) nyatoh, 370x magnification, (b) pisang putih, 350x magnification, and (c) sepetir, 350x magnification. Note: arrow indicates boron traces.

and $44 \%$ for borax compounds. Therefore, the increase of SG in this research was not caused by boron impregnation but by flattening wood cells during densification.

Fig. 3 shows the increasing in SG of the three treated wood compared to that of control wood. The results indicate that increasing in SG varied greatly on each species. In case of pisang putih it was $38.36-63.03 \%$, in sepetir $30.49-53.37 \%$, and in nyatoh $28.86-49.96 \%$. Higher increasing of SG in pisang putih was related to its anatomical structure especially larger diameter of fiber and vessel cells as well as the greatest portion of its ray parenchyma (Fig. 4) and its initial SG. Larger diameter of fiber and vessel was significantly influenced the reduction of void volume during densification, and resulted in the increase in SG. Macroscopic observations show that pisang putih wood underwent severe damage than those of sepetir and nyatoh.

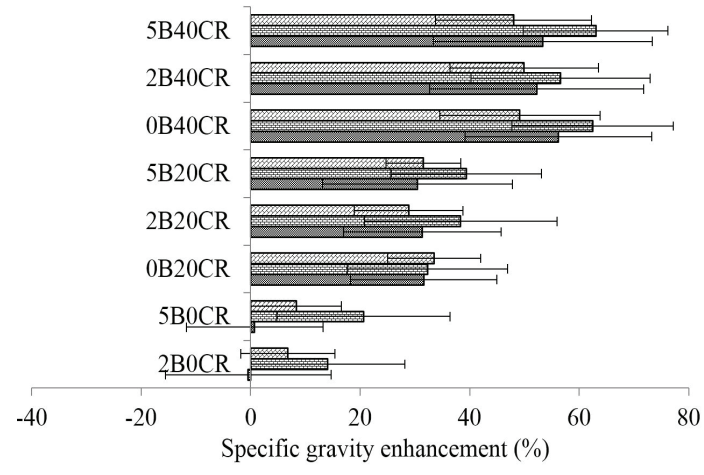

Fig. 3. Specific gravity enhancement of three wood species at different boron concentrations and different compression ratios. Note: I. sepetir.

Its ray parenchyma was more buckling, while its fibers and vessels were flatter (Fig. 5). This phenomenon coincided with Darwis et al. (2017). They mentioned that densification results in flattening in lumen cell of 

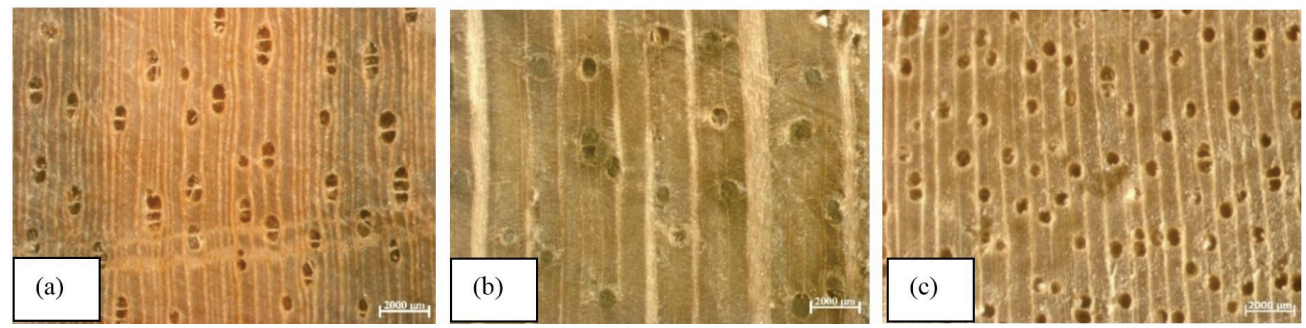

Fig. 4. Cross section of each wood species: (a) nyatoh, (b) pisang putih, and (c) sepetir; 12.5x magnification.
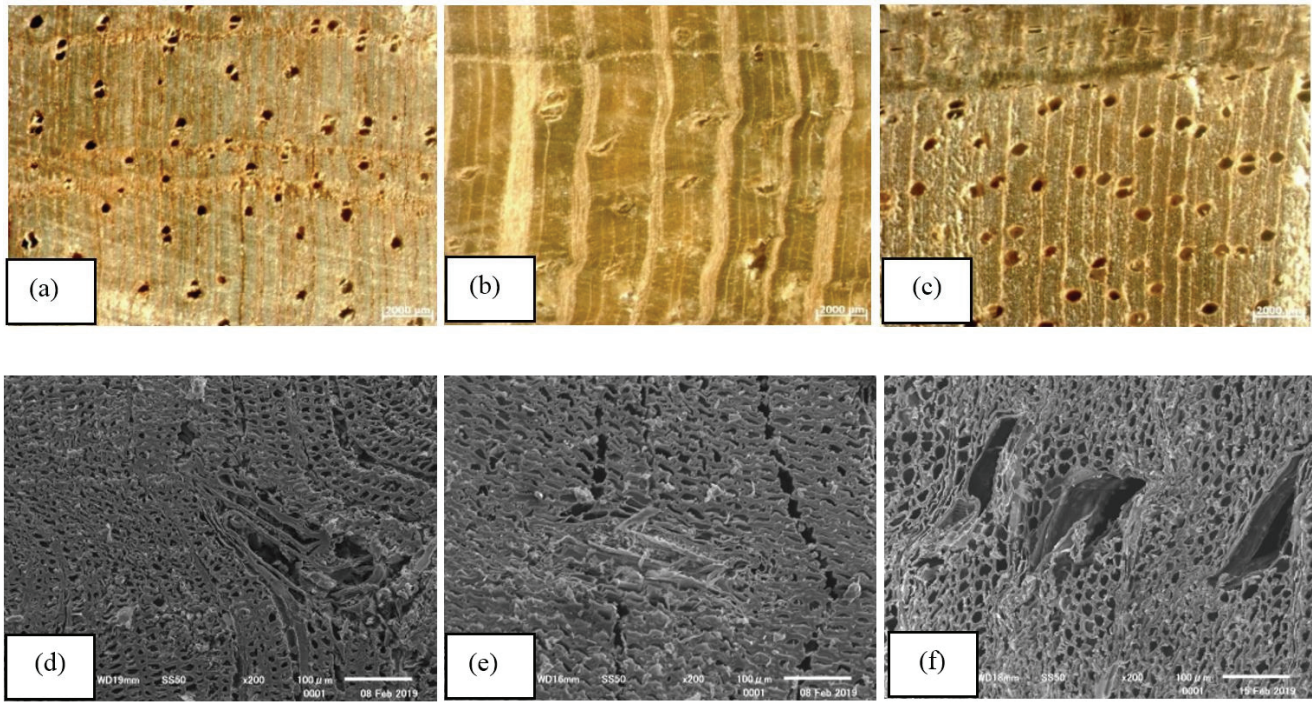

Fig. 5. Changes in cell structure of three wood species after densification observed with macroscopic microscope: (a) nyatoh, (b) pisang putih, and (c) sepetir, 12.5x magnification, and flattened fibers and vessels observed with Scanning Electron Microscope: (d) nyatoh, (e) pisang putih, and (f) sepetir; 200x magnification.

vessels and fibers, while ray parenchyma becomes buckling. These changes are more significant along with increasing in compression ratio. These phenomena are similar to Budakci et al. (2016). They stated that cell deformation becomes more severe with increasing of compression ratio.

Fig. 3 also shows that SG increased along with the increase of compression ratio. After densification at 20 and $40 \%$ of compression ratio, SG increased by 28.86-39.36\% and 48.01-63.03\% compared those of control, respectively. The $40 \%$ compression ratio treat- ment resulted in the highest of SG improvement due to the increasing number of flattened cell cavities. After densification at $40 \%$ compression ratio, void volume decreased significantly (Table 4). This phenomenon is similar to that of Ulker et al. (2012) and Miyoshi et al. (2016). Densified Scots pine wood (Ulker et al., 2012) and Japanese cedar wood (Miyoshi et al., 2016) at temperature of $160^{\circ} \mathrm{C}$ and $50 \%$ of compression ratio result in an increase of wood density up to $93 \%$ and double in SG. Similar result was also found on thermally compressed of Korean pine wood 
Specific Gravity and Dimensional Stability of Boron-Densified Wood on Three Lesser-Used Species from Indonesia

Table 4. Anatomical characteristics of three wood species

\begin{tabular}{lccc}
\hline \multicolumn{1}{c}{ Parameters } & \multicolumn{3}{c}{ Wood species } \\
\cline { 2 - 4 } & Nyatoh & Pisang Putih & Sepetir \\
\hline \hline Fiber diameter $(\mu \mathrm{m})$ & $32.22 \pm 1.43$ & $32.60 \pm 1.04$ & $18.23 \pm 0.34$ \\
Vessel diameter $(\mu \mathrm{m})$ & $89.37 \pm 5.21$ & $103.33 \pm 1.53$ & $8-19 \pm 7.23$ \\
Ray parenchyma portion $(\%)$ & $7-15$ & $15-25$ & 76.45 \\
Initial void volume $(\%)$ & 70.29 & 72.57 & 67.13 \\
Void volume after 20\% densification $(\%)$ & 56.70 & 59.63 & 59.32 \\
Void volume after 40\% densification $(\%)$ & 48.18 & 48.29 & 2 \\
\hline
\end{tabular}

with 50\% compression ratio (Lee and Lee, 2018) and laminated board of oil palm trunk (Prabuningrum et al., 2020) with 33\% compression ratio.

Densification process resulted in a reduction of void volume value around 9.12-17.57\% (Table 4). This result indicates that densification occurred primarily on wood surface (partially densification). Microscopic observations proved that all woods species underwent surface densification (Fig. 5). Ray buckling and cell flattening were severely occurred on wood surface, while at the center the changes were not significant. The results are coincided to Hill (2006) and Darwis et al. (2017). They stated that wood surface receives the highest load during densification so that wood cells on the surface are more damaged compared with those at the center.

\subsection{Compression-set and compression-set recovery}

Fig. 6 shows c-set value of the three treated woods. It can be seen that c-set value varied greatly on each wood species and each compression ratio, but almost constant on each boron concentration. C-set value of nyatoh wood was $25.47 \%$ for both compression ratios, while in cases of pisang putih and sepetir woods were 25.82 and $27.10 \%$, respectively. Among wood species, sepetir had the highest c-set, while pisang putih and nyatoh were almost similar. The highest c-set value

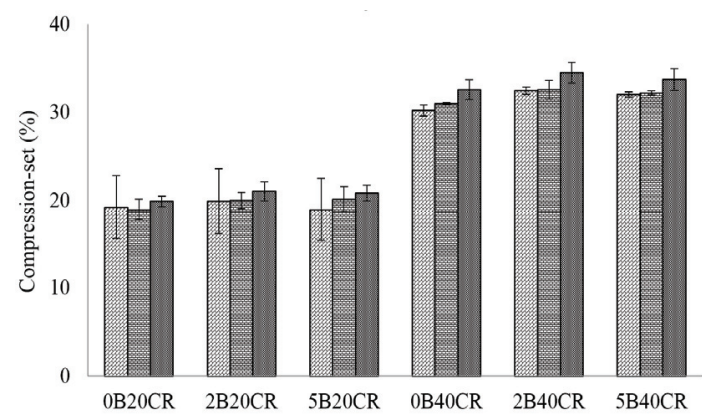

Fig. 6. Compression-set of three wood species at different boron concentrations and different compression ratios. Note: 国 : nyatoh, 罟 : pisang putih, $\square$ : sepetir.

in sepetir was related to the lowest initial SG of this species which resulted in the highest reduction in total void volume after densification. Lower SG indicates more porous the wood (Hill, 2006). Porous wood result in higher total void volume. Higher void volume will lead higher rate of deformation in the lumens cell (Tu et al., 2014).

Analysis of variance shows that wood species, compression ratio, and pre-treatment had significant effect on c-set value $(\mathrm{P}<0.05)$. Compression-set of nyatoh was similar to that of pisang putih, but their values were different from that of sepetir. C-set values increased along with the increase of compression ratio. At $20 \%$ and $40 \%$ of compression ratio, c-set values of three wood species were $18.95-21.05 \%$ and $30.22-$ $34.49 \%$, respectively. This phenomenon was related to 
the increasing number of flattened cell cavities. Inoue et al. (1993) reported that SG of modified sugi wood increases from 0.36 (initial) to 0.50 with $30 \%$ compression-set, and up to 0.90 with $60 \%$ compression-set.

Compared with densified wood without pre-treatment, the c-set value of densified wood with pre-treatment increases by $3.52-7.45 \%$. This result indicates that pre-treatment applied resulted in increasing compressibility of the wood. When wood temperature is above transition glass, amorphous polymer easily rearanged without any major deformation or fracture (Budakci et al., 2016). According to Khalil et al. (2014); Navi and Sandberg (2012), hot immersion results in wood softened so that the cell wood is easier to be flatten during densification.

Compression-set recovery is thickness swelling of densified wood after water soaking process. The values of CSR are presented in Fig. 7. Analysis of variance shows that wood species, compression ratio, and pre-treatment had significant effect on CSR $(\mathrm{P}<0.05)$. The CSR of nyatoh was $45.88 \%$ for both compression ratios, while CSR of pisang putih and sepetir were 53.20 and $45.20 \%$, respectively. Among wood species, pisang putih had the highest of CSR which was significantly different with nyatoh and sepetir. Highest CSR in pisang putih was related to its anatomical characteristics especially vessel diameter. Highest vessel diameter resulted in the highest reduction in void volume due to the collapse of wood cell. Highest portion in flattening cell had more energy to return to its initial size and form.

It can be seen that CSR increased significantly along with the increasing of compression ratio. At 20 and $40 \%$ of compression ratio, CSR of three wood species were $38.35-54.04 \%$ and $40.69-58.44 \%$, respectively. This phenomenon was also related to anatomical structure especially the number of flattened cells.

Analysis of variance shows that CSR was influ-

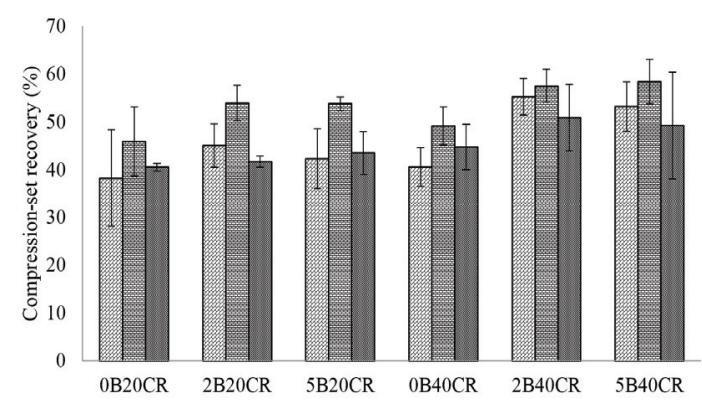

Fig. 7. Compression-set recovery of three wood species at different boron concentrations and different compression ratios. Note: 面 : nyatoh, 橉 : pisang putih, D: sepetir.

enced by pre-treatment., however, there was no significant effect of boron concentrations. Average values of CSR after pre-treatment with 2 and $5 \%$ boron were 50.82 and $50.12 \%$, respectively; however, it was significantly different from that of densified wood without pre-treatment $(28.87 \%)$. It was happened due to the presence of boric acid which has a hygroscopic characteristic. In another study, Laine et al. (2013) reported that CSR is also affected by mechano-sorptive phenomenon which is closely related to the condition under pressure (densification) and variation of moisture content that usually occurred during the desorption process. Increasing of moisture content will induce the stress release.

\subsection{Thickness swelling}

Table 5 shows thickness swelling of densified wood after water soaking for 24 hours. Analysis of variance also shows that wood species, compression ratio, and pre-treatment had significant effect on thickness swelling $(\mathrm{P}<0.05)$. According to Table 5, average thickness swelling of nyatoh was similar to that of pisang putih (2.71 and $2.72 \mathrm{~mm}$ ), but different from that of sepetir (2.91 mm). Average thickness swelling after densification at $20 \%$ compression ratio $(2.59 \mathrm{~mm})$ was significantly different from $40 \%$ of compression ratio (4.99 
Table 5. Thickness swelling of three wood species at different boron solution concentrations and different compression ratios

\begin{tabular}{|c|c|c|c|}
\hline \multirow{3}{*}{ Treatments } & \multicolumn{3}{|c|}{ Thickness swelling (mm) } \\
\hline & \multicolumn{3}{|c|}{ Species } \\
\hline & Nyatoh & Pisang Putih & Sepetir \\
\hline None (control) & $0.89 \pm 0.20^{\mathrm{a}}$ & $0.65 \pm 0.16^{\mathrm{a}}$ & $0.91 \pm 0.17^{\mathrm{a}}$ \\
\hline 2B0CR & $0.73 \pm 0.16^{\mathrm{a}}$ & $0.68 \pm 0.14^{\mathrm{a}}$ & $0.80 \pm 0.37^{\mathrm{a}}$ \\
\hline $5 \mathrm{~B} 0 \mathrm{CR}$ & $0.73 \pm 0.15^{\mathrm{a}}$ & $0.68 \pm 0.22^{\mathrm{a}}$ & $0.75 \pm 0.29^{\mathrm{a}}$ \\
\hline 0B20CR & $2.32 \pm 0.49^{\mathrm{b}}$ & $2.36 \pm 0.52^{\mathrm{bc}}$ & $2.52 \pm 0.36^{\mathrm{bcd}}$ \\
\hline 2B20CR & $2.65 \pm 0.48^{\mathrm{cd}}$ & $2.70 \pm 0.37^{\mathrm{d}}$ & $2.77 \pm 0.34^{\mathrm{d}}$ \\
\hline $5 \mathrm{~B} 20 \mathrm{CR}$ & $2.57 \pm 0.50^{\text {bcd }}$ & $2.69 \pm 0.45^{\mathrm{d}}$ & $2.73 \pm 0.44^{\mathrm{d}}$ \\
\hline 0B40CR & $4.23 \pm 0.34^{\mathrm{e}}$ & $4.53 \pm 0.49^{\mathrm{f}}$ & $5.00 \pm 0.46^{\mathrm{g}}$ \\
\hline 2B40CR & $5.14 \pm 0.35^{\mathrm{g}}$ & $5.19 \pm 0.63^{g}$ & $5.58 \pm 0.58^{\mathrm{h}}$ \\
\hline 5B40CR & $5.10 \pm 0.32^{\mathrm{g}}$ & $5.03 \pm 0.41^{\mathrm{g}}$ & $5.11 \pm 0.74^{\mathrm{g}}$ \\
\hline
\end{tabular}

Note: Thickness values are averages of 15 replications. Values within a column followed by the same letter are not significantly different at 5\% significance level using Duncan's multiple range test.

$\mathrm{mm})$. These values were also significantly different from that of control wood $(0.76 \mathrm{~mm})$.

Compared to that of control wood, thickness swelling of densified wood increased significantly along with increasing compression ratio. Increasing of thickness swelling was around 182.40 and $441.95 \%$ for nyatoh, 297.43 and $656.41 \%$ for pisang putih, and 193.77 and $474.72 \%$ for sepetir with 20 and $40 \%$ compression ratios, respectively. It also can be seen on Table 5, thickness swelling of densified wood was prominently higher than that of densified wood without pre-treatment.

Analysis of variance shows that thickness swelling was influenced by pre-treatment, but there was no effect of boron concentration. Thickness swelling of wood after hot soaking within 2 and $5 \%$ boron were $2.92 \mathrm{~mm}$ and $2.82 \mathrm{~mm}$, respectively. These values were significantly different from that of densified wood without pre-treatment $(2.60 \mathrm{~mm})$. It also can be seen on Table 5, thickness swelling of densified wood with pre-treatment increased around $8.01-16.77 \%$ compared with densified wood without pre-treatment. Nagieb et al. (2011) and Baysal et al. (2006) noted that treated wood with inorganic salts such as boron compounds is usually more hygroscopic than untreated wood especially in high humidity. It can be considered that densified wood without pre-treatment was more stable than densified wood with pre-treatment.

Generally, increasing in thickness swelling is related to reversible and irreversible reactions during immersion, especially for densified wood. Reversible swelling is caused by the natural hygroscopicity of wood, while irreversible swelling is caused by the CSR (Fang et al., 2012). Irreversible swelling can also occur due to mechanical failure of covalent bonds between hemicellulose and lignin when the development stress exceeds the bond strength between the two (Ohlmeyer and Paul, 2010).

\subsection{Water absorption}

Thickness swelling of densified wood related to its ability to absorb water and attempts to restore the cell structure to its initial form. Rowel and Young (1981) stated that when moisture contacts with wood, the water molecules penetrate the cell wall and bound into 
Table 6. Water absorption of three wood species at different boron solution concentrations and different compression ratios

\begin{tabular}{|c|c|c|c|}
\hline \multirow{3}{*}{ Treatments } & \multicolumn{3}{|c|}{ Water absorption (\%) } \\
\hline & \multicolumn{3}{|c|}{ Species } \\
\hline & Nyatoh & Pisang Putih & Sepetir \\
\hline None (control) & $92.52 \pm 17.30^{\mathrm{c}}$ & $1333.30 \pm 20.32^{\mathrm{i}}$ & $105.26 \pm 17.47^{\mathrm{c}}$ \\
\hline 2B0CR & $98.22 \pm 11.58^{\text {cde }}$ & $122.47 \pm 25.04^{\mathrm{hi}}$ & $134.92 \pm 36.39^{\mathrm{i}}$ \\
\hline $5 \mathrm{~B} 0 \mathrm{CR}$ & $99.22 \pm 13.05^{\text {cdef }}$ & $121.92 \pm 26.21^{\mathrm{ghi}}$ & $116.33 \pm 37.82^{\mathrm{fgh}}$ \\
\hline 0B20CR & $63.93 \pm 12.05^{\mathrm{a}}$ & $104.27 \pm 26.9^{\text {cdefg }}$ & $74.69 \pm 14.78^{\mathrm{ab}}$ \\
\hline 2B20CR & $88.26 \pm 10.64^{\mathrm{bc}}$ & $113.86 \pm 26.47^{\mathrm{efgh}}$ & $94.84 \pm 12.88^{\mathrm{cd}}$ \\
\hline $5 \mathrm{~B} 20 \mathrm{CR}$ & $93.84 \pm 12.20^{\mathrm{cd}}$ & $110.97 \pm 21.56^{\operatorname{defgh}}$ & $116.45 \pm 13.03^{\mathrm{fgh}}$ \\
\hline 0B40CR & $64.00 \pm 11.47^{\mathrm{a}}$ & $98.93 \pm 25.31^{\text {cdef }}$ & $90.29 \pm 15.09^{b c}$ \\
\hline 2B40CR & $92.19 \pm 11.22^{\mathrm{c}}$ & $115.58 \pm 19.94^{\mathrm{efgh}}$ & $114.70 \pm 25.12^{\text {efgh }}$ \\
\hline 5B40CR & $98.06 \pm 17.69^{\text {cde }}$ & $105.41 \pm 21.53^{\text {cdefgh }}$ & $113.86 \pm 18.26^{\text {efgh }}$ \\
\hline
\end{tabular}

Note: Water absorption values are averages of 15 replications. Values within a column followed by the same letter are not significantly different at $5 \%$ significance level using Duncan's multiple range test.

it through hydrogen bonding. With addition of water, wood volume increases (wood cell wall swelling) until it is reached the fiber saturation point. Average value of water absorption obtained in this study is presented in Table 6.

Water absorption of densified wood without pretreatment was slightly lower compared to that of control. Analysis of variance shows that wood species, compression ratio, and pre-treatment had significant effect on water absorption $(\mathrm{P}<0.05)$. Water absorption of densified wood were different among the three species. The average WA values were 87.97, 114.08, and $106.68 \%$ for nyatoh, pisang putih, and sepetir, respectively. The lowest water absorption in nyatoh densified wood indicates that the fixation occurred in this species during densification was more completed. This finding coincided with previous study reported by Bao et al. (2016). Triadi et al. (2019) also added that higher SG wood has a lower water absorption value due to lower porosity (cell cavities) and permeability. Similar findings were also reported on bam- boo fiber-based composite (Zhang et al., 2018) and medium density fiberboard panels (Hong et al., 2017). Average values of WA after densification at 20 and $40 \%$ of compression ratios were 95.71 and $99.23 \%$, respectively. However, their values were different from that of control wood (113.79\%). This indicates that densified wood was more stable.

Water absorption of densified wood without pretreatment was significantly different from densified wood with pre-treatment, however, there was no significant effect of boron concentration. Average value of WA after pre-treatment with 2 and $5 \%$ of boron were 108.37 and $108.45 \%$, respectively. These values were higher than that of densified wood without pretreatment $(91.91 \%)$. This phenomenon indicates that boron was contributed to the increasing of WA. According to Kartal et al. (2007), WA in boric acid impregnated wood increases by $200 \%$ during water soaking for 24 hours. 


\section{CONCLUSION}

Hot soaking within 2 and $5 \%$ of boron solutionsas pre-treatment-has no effect on SG improvement, while pre-treatment followed by densification can improve SG of wood significantly. Specific gravity of densified wood was influenced by wood species and compression ratio. The higher of compression ratio results in the higher improvement of SG. This improvement is in line with improvement of C-set and CSR. Dimensional stability improvement was influenced by wood species, compression ratio, and pre-treatment applied. The higher of compression ratio results in the higher improvement of water absorption, but not the thickness swelling. Water absorption decreased 12.80$15.89 \%$, while thickness swelling of $20 \%$ of compression ratio treatment was lower than that of $40 \%$ of compression ratio. Densified wood without pretreatment provides a better dimensional stability.

\section{ACKNOWLEDGMENT}

The authors are grateful for the support of Ministry of Research, Technology and Higher Education of the Republic of Indonesia through PMDSU No. 1053/IT3.11/LT/2017.

\section{REFERENCES}

Ali, C.A. 2011. Physical-mechanical properties and natural durability of lesser used wood species from Mozambique [dissertation]. Uppsala (SWE): Swedish University of Agricultural Sciences.

[BPS] Badan Pusat Statistik. 2017. Forest production's statistic 2016. Jakarta (ID): Statistics Indonesia. (in Bahasa Indonesia).

Bal, B.C., Bektas, I. 2012. The effect of heat treatment on the physical properties of juvenile wood and mature wood of Eucalyptus grandis. Bioresources 7(4): 5117-5127.

Bao, M., Huang, X., Zhang, Y., Yu, Y. 2016. Effect of density on the hygroscopicity and surface characteristics of hybrid poplar compreg. Journal of Wood Science 62(5): 441-451.

Baysal, E., Sonmez, A., Colak, M., Toker, H. 2006. Amount of leachant and water absorption levels of wood treated with borates and water repellents. Bioresources Technology 97(18): 2271-2279.

Bucur, V., Garros, S., Barlow, C.Y. 2000. The effect of hydrostatic pressure on physical properties and microstructure of spruce and cherry. Holzforschung 54(1): 83-92.

Budakci, M., Pelit, H., Sönmez, A., Korkmaz, M. 2016. The effect of densification and heat post-treatment on hardness and morphological properties of wood. Bioresources 11(3): 7822-7838.

Danu, S., Razzak, T.M., Handono, D., Darsono, Marsongko. 2013. Densification of Randu wood (Ceiba pentandra L. Gaertn) and surface coating by compaction using ultra violet radiation. Indonesian Journal Material of Science 14(3): 222-228. (in Bahasa Indonesia).

Darwis, A., Wahyudi, I., Dwianto, W., Cahyono, T.D. 2017. Densified wood anatomical structure and the effect of heat treatment on the recovery of set. Journal of The Indian Academic of Wood Science 14(1): 24-31.

Fang, C.H., Mariotti, N., Cloutier, A., Koubaa, A., Blanchet, P. 2012. Densification of wood veneers by compression combined with heat and steam. European Journal of Wood and Wood Products 70(1-3): 155-163.

[FAO] Food and Agriculture Organization of the United Nations. 1984. Lesser-Known Tropical Wood Species. Rome (IT): FAO Forestry Paper 36.

Furuta, Y., Aizawa, H., Yano, H., Norimoto, M. 1997. Thermal-softening properties of water-swollen wood: IV. Effects of chemical constituents of the cell wall on the thermal-softening properties of wood. Mokuzai Gakkaishi 43(9): 725-730.

Gašparik, M., Barcik, Š. 2014. Effect of plasticizing by microwave heating on bending characteristics 
of Beech wood. Bioresources 9(3): 4808-4820.

Hill, C.A.S. 2006. Wood modification: Chemical, thermal, and other processes. Chichester, Sussex (UK): John Wiley and Sons.

Hong, M.K., Park, B.D., Lubis, M.A.R. 2017. Effect of panel density and resin content on properties of medium density fiberboard. Journal of the Korean Wood Science and Technology 45(4): 444-455. Inoue, M., Norimoto, M., Tanahashi, M., Rowel, R.M. 1993. Steam or heat fixation of compressed wood. Wood and Fiber Science 25(3): 224-235.

Kartal, S.N., Hwang, J.W., Imamura, Y. 2007. Water absorption of boron-treated and heat-modified wood. Journal of Wood Science 53(5): 454-457.

Kelley, S.S., Timothy, G.R., Glasser, W.G. 1987. Relaxation behavior of the amorphous components of wood. Journal of Material Science 22(2): 617624.

Khalil, A.H.P.S., Dungani, R., Mohammed, I.A., Hossain, S.Md., Aprilia, S.N.A., Budiarto, E., Rosamah, E. 2014. Determination of the combined effect of chemical modification and compression of Agathis wood on the dimensional stability, termite resistance, and morphological structure. Bioresources 9(4): 6614-6626.

Kong, L., Zhao, Z., He, Z., Yi, S. 2017. Effect of steaming treatment on crystallinity and glass transition temperature of Eucalyptuses grandis $\mathrm{x}$ E. urophylla. Results in Physics 7: 914-919.

Korkut, D.S., Korkut, S., Bekar, I., Budakçı, M., Dilik, T., Çakıcıer, N. 2008. The effects of heat treatment on the physical properties and surface roughness of Turkish Hazel (Corylus colurna L.) wood. International Journal of Molecular Sciences 9(9): 1772-1783.

Lahtela, V., Karki, T. 2014. Effects of impregnation and heat treatment on the physical and mechanical properties of Scots pine (Pinus sylvestris) wood. Wood Material Science and Engineering 11(4): 217-227.
Laine, K., Belt, T., Rautkari, L., Ramsay, J., Hill, C.A.S., Hughes, M. 2013. Measuring thickness swelling and set-recovery of densified and thermally modified Scot pine solid wood. Journal of Materials Science 48(24): 8530-8538.

Laine, K., Segerholm, K., Wålinder, M., Rautkari, L., Ormondroyd, G., Hughes, M., Jones, D. 2014. Micromorphological studies of surface densified wood. Journal of Materials Science 49: 2027-2034.

Laser, B., Gorisek, Z., Humar, M. 2009. Sorption properties of wood impregnated with boron compounds, sodium chloride and glucose. Drying Technology 27(1): 94-102.

Lee, J.M., Lee, W.H. 2018. Dimensional stabilization through heat treatment of thermally compressed wood of Korean pine. Journal of the Korean Wood Science and Technology 46(5): 471-485.

Li, J., Furuno, T., Katoh, S., Uehara, T. 2000. Chemical modification of wood by anhydrides without solvents or catalysts. Journal of Wood Science 46: 215-221.

Marbun, S.D., Wahyudi, I., Suryana, J., Nawawi, D.S. 2019. Anatomical structures and fiber quality of four lesser-used wood species grown in Indonesia. Journal of the Korean Wood Science and Technology 47(5): 617-632.

Martawijaya, A., Kartasujana, I., Mandang, Y.I., Prawira, S.A., Kadir, K. 1989. Atlas Kayu Indonesia Jilid II. Bogor (ID): The forestry research, development and innovation agencies. (in Bahasa Indonesia).

Miyoshi, Y., Furutani, M., Furuta, Y. 2016. Swelling behavior of cells in compressed wood. Journal of the Society of Materials Science 65(5): 343-346.

Morsing, N., Hoffmeyer, P. 2000. Densification of wood: The influence of hygrothermal treatment on compression of beech perpendicular to gain [dissertation]. Denmark (DK): Technical University of Denmark.

Nagieb, Z.A., Nassar, M.A., El-Meligy, M.G. 2011. 
Specific Gravity and Dimensional Stability of Boron-Densified Wood on Three Lesser-Used Species from Indonesia

Effect of addition of boric acid and borax on fireretardant and mechanical properties of urea formaldehyde saw dust composites. International Journal of Carbohydride Chemistry 2011: 1-6.

Navi, P., Sandberg, D. 2012. Thermo hydro mechanical processing of wood. Lausanne $(\mathrm{CH})$ : EPFL Press.

Ohlmeyer, M., Paul, W. 2010. Optimization of the Properties of Wood Materials by Means of Thermal Modification Methods (Work Report No. 2010/2). Hamburg (DE): Institute of Wood Technology and Wood Biology, University of Hamburg.

Prabuningrum, D.S., Massijaya, M.Y., Hadi, Y.S., Abdillah, I.B. 2020. Physical-mechanical properties of laminated board made from oil palm trunk (Elaeis guineensis Jacq.) waste with various lamina compositions and densifications. Journal of the Korean Wood Science and Technology 48(2): 196-205.

Ramos, A.M., Jorge, F.C., Botelho, C. 2006. Boron fixation in wood: studies of fixation mechanisms using model compounds and maritime pine. Holz Roh Werkst 64(6): 445-450.

Rowel, R.M., Young, R.L. 1981. Dimensional Stabilization of Wood in Use. FPL-0243, Madison, WI (US): U.S. Department of Agriculture, Forest Service, Forest Products Laboratory.

Rowell, R.M. 1990. Chemical modification of lignocellulosic fibers to produce high- performance composites. Materials Research Society Symposium Proceedings 197: 3-9.

Rulliaty, S. 1994. Wood quality indicators as estimator of juvenile wood in Mahagony (Swietenia macropylla King) from forest plantation in Sukabumi, West Java, Indonesia [Thesis]. Los Banos (PH): UPLB.

Shmulsky, R., Jones, P.D. 2011. Forest products \& wood science: An introduction $6^{\text {th }}$ ed. West Sussex (GB): Wiley-Blackwell.

Triadi, P., Sholihah, M., Karlinasari, L. 2019. Water absorption and dimensional stability of heat-treated fast-growing hardwoods. Journal of the Korean Wood Science and Technology 47(5): 567-578.

Tu, D., Su, T., Zhang, T., Fan, W., Zhou, Q. 2014. Thermo-mechanical densification of Populus tomentosa var. tomentosa with low moisture content. Bioresources 9(3): 3846-3856.

Ulker, O., Imirzi, O., Burdurlu, E. 2012. The effect of densification temperature on some physical and mechanical properties of scots pine (Pinus sylvestris L.). Bioresources 7(4): 5581-5592.

Ulvcrona, T., Linberg, H., Bergsten, U. 2006. Impregnation of Norway spruce (Picea abies L. Karst.) wood by hydrophobic oil and dispersion patterns in different tissues. Forestry 79(1): 123-134.

Wistara, N.J., Rohmatullah, M.A., Febrianto, F., Pari, G., Lee, S.H., Kim, N.H. 2017. Effect of bark content and densification temperature on the properties of oil palm trunk-based pellets. Journal of the Korean Wood Science and Technology 45(6): 671-681.

Yunianti, A.D., Tirtayasa, K.P., Suhasman, Taskirawati, I., Agussalim, Muin, M. 2019. Modified densification process for increasing strength properties of Pine and Gmelina wood from community forests. Journal of the Korean Wood Science and Technology 47(4): 418-424.

Zhang, Y.H., Huang, Y.X., Ma, H.X., Yu, W.J., Qi, Y. 2018. Effect of different pressing processes and density on dimensional stability and mechanical properties of bamboo fiber-based composites. Journal of the Korean Wood Science and Technology 46(4): 355-361.

Zhao, Y., Wang, Z., Iida, I., Huang, R., Lu, J., Jiang, J. 2015. Studies on pre-treatment by compression for wood drying I: Effect of compression ratio, compression direction and compression speed on the reduction of moisture content in wood. Journal of Wood Science 61(2): 113-119. 